\title{
POPULATION OF UKRAINIAN PHYSIOGRAPHIC REGIONS AND ITS PROVISION WITH NATURE- RESOURCE POTENTIAL
}

\author{
Valeriy RUDENKO, Stepan RUDENKO, Hanna YEREMIYA \\ Yuriy Fedkovych Chernivtsi National University, Ukraine \\ clg-geog@chnu.cv.ua
}

\begin{abstract}
The aim of the article is to calculate the population of physiographic regions of Ukraine and to define its provision with the natural resource potential. Population of 278 physiographic regions, 57 physiographic oblasts, 14 physiographic provinces, 3 physiographic sub-zones, 4 physiographic zones, and 3 physiographic countries of the Ukrainian state was calculated using a map overlay method. Distribution of the population by physiographic regions of Ukraine gave a possibility to calculate the socio-economic proportions and balances for genetically existing natural resource systems, combining natural and social productive forces. Analysis of the provision of physiographic regions with the natural resource potential allows revealing the latent reserves of further balanced natural resource development of the Ukrainian state.
\end{abstract}

Key words: population number, natural (physic-geographical) regions of Ukraine, provision with nature-resource potential.

UDC: 94.3: $330.15(914.77)$

\section{НАСЕЛЕННЯ ФІЗИКО-ГЕОГРАФІЧНИХ РЕГІОНІВ УКРАЇНИ ТА ЙОГО ЗАБЕЗПЕЧЕНІСТЬ ПРИРОДНО-РЕСУРСНИМ ПОТЕНЦІАЛОМ}

\author{
Валерій РУДЕНКО, Степан РУДЕНКО, Ганна ЄРЕМІЯ \\ Чернівецький начіональний університет імені Юрія Федьковича, Україна \\ clg-geog@chnu.cv.ua
}

\begin{abstract}
Анотація: Метою статті $\epsilon$ визначення чисельності населення фізико-географічних регіонів України та розрахунок рівнів його забезпеченості природно-ресурсним потенціалом. За допомогою картографічного методу розраховано чисельність населення 278 фізико-географічних районів, 57 областей, 14 країв, 3 підзон, 4 зон, 3 країн Української держави. Отримані показники чисельності населення у розрізі природних регіонів України дають можливість розраховувати соціально-економічні пропорції, балансиза генетичносформованимиприродно-ресурсними комплексами, щопоєднують всобі природнітасуспільні продуктивні сили. Проаналізовані рівні забезпеченості природних регіонів України природно-ресурсним потенціалом, що дозволяє виявляти приховані резерви подальшого збалансованого природно-ресурсного розвитку Української держави.

Ключові слова: населення, фізико-географічні регіоні України, природно-ресурсний потенціал.
\end{abstract}

Удк: 94.3: $330.15(914.77)$

Вступ. Постановка проблеми. У 2003 p. опублікована удосконалена схема фізикогеографічного районування України, проведеного під керівництвом члена-кореспондента НАН України O.M. Маринича [2]. Вона підсумувала результати багаторічних наукових досліджень географівкомплексників, що здійснювались у даній галузі впродовж 1968 - 2003 р.p.[3].

Удосконалена схема фізико-географічного районування стала основою вартісної переоцінки природно-ресурсного потенціалу (ПРП) України та його наступних суспільно-географічних досліджень [4]. Разом $з$ тим подальші географічні аналіз і синтез стримуються відсутністю такої вкрай важливої інформації як кількість населення природних регіонів України, яка фіксується, як відомо, за адміністративно-територіальними одиницями держави.

Саме тому метою даної публікації є, 3 одного боку, визначення чисельності населення фізикогеографічних регіонів України, а з другого боку, - розрахунок рівнів його забезпеченості природноресурсним потенціалом.

(C) В. Руденко, С. Руденко, Г. Єремія
Методичні підходи. Чисельність населення фізико-географічних районів, областей, країв, підзон, зон, країн України визначалась за матеріалами офіційної статистики станом на 1 січня 2010 р. картографічним методом [1]. Для цього картосхема фізико-географічних регіонів накладалась на карту щільності населення України в розрізі адміністративних районів в масштабі 1:750000. Кількість мешканців фізико-географічних районів, межі яких розчленовували той чи інший адміністративний район, оцінювалась методом палетки за картограмами щільності населення адміністративних районів. Визначена таким чином чисельність населення стала основою для оцінки рівнів його забезпеченості сумарним ПРП. В таблиці 1 у зв'язку з обмеженим обсягом статті подані отримані оцінкові результати лише на рівні фізико-географічних областей, країв, підзон, зон, країн України.

Аналіз та обговорення результатів. Як видно 3 приведених матеріалів, серед природних країн Східно-Свропейська рівнина зосереджує майже 9/10 всього населення Української держави, Українські Карпати - близько 8\%, Кримські гори - майже 3 \%.

У Степовій зоні проживає більше 2/5, у 
Таблиия 1

Чисельність населення фізико-географічних регіонів України та його забезпеченість природно-ресурсним потенціалом (складено за матеріалами [1])

\begin{tabular}{|c|c|c|c|c|}
\hline \multirow{2}{*}{ Фізико-географічний регіон } & \multicolumn{2}{|c|}{ Чисельність населення } & \multicolumn{2}{|c|}{$\begin{array}{l}\text { Забезпеченість } \\
\text { населення ПРП }\end{array}$} \\
\hline & тис. осіб & $\%$ & $\begin{array}{l}\text { тис. грн. / } \\
\text { особу }\end{array}$ & у балах \\
\hline 1 & 2 & 3 & 4 & 5 \\
\hline СХІДНО-ЄВРОПЕЙСЬКА РІВНИНА & 40919,48 & 89,02 & 6,05 & 103 \\
\hline Зона мішаних лісів & 5070,57 & 11,03 & 4,93 & 84 \\
\hline Поліський край & 5070,57 & 11,03 & 4,93 & 84 \\
\hline I. Область Волинського Полісся & 997,48 & 2,17 & 5,16 & 88 \\
\hline II. Область Малого Полісся & 590,68 & 1,29 & 4,25 & 72 \\
\hline III. Область Житомирського Полісся & 1094,77 & 2,38 & 4,25 & 72 \\
\hline IV. Область Київського Полісся & 1040,94 & 2,26 & 3,03 & 52 \\
\hline V. Область Чернігівського Полісся & 1137,5 & 2,47 & 5,16 & 88 \\
\hline VI. Область Новгород-Сіверського Полісся & 209,2 & 0,46 & 11,20 & 191 \\
\hline Зона широколистяних лісів & 5074,97 & 11,04 & 4,38 & 75 \\
\hline Західно-Украӥнський край & 5074,97 & 11,04 & 4,38 & 75 \\
\hline VII. Волинська височинна область & 1157,17 & 2,52 & 3,28 & 56 \\
\hline VIII. Розточько-Опільська горбогірна область & 1374,23 & 2,99 & 2,93 & 50 \\
\hline ІХ.Західно-Подільська височинна область & 1094,52 & 2,38 & 3,96 & 67 \\
\hline Х. Середньоподільська височинна область & 1017,2 & 2,21 & 6,62 & 113 \\
\hline ХІ. Прут-Дністровська височинна область & 431,85 & 0,94 & 7,67 & 131 \\
\hline Лісостепова зона & 12195,67 & 26,53 & 4,99 & 85 \\
\hline Подільсько-Придніпровський край & 6106,39 & 13,28 & 5,13 & 87 \\
\hline $\begin{array}{l}\text { ХII. Північно-Західна Придніпровська височинна } \\
\text { область }\end{array}$ & 471,78 & 1,03 & 6,54 & 111 \\
\hline $\begin{array}{l}\text { ХIII. Північно-Східна Придніпровська височинна } \\
\text { область }\end{array}$ & 630,63 & 1,37 & 6,63 & 113 \\
\hline XIV. Київська височинна область & 1264,58 & 2,75 & 2,30 & 39 \\
\hline $\begin{array}{l}\text { XV. Придністровсько-Східно-Подільська височинна } \\
\text { область }\end{array}$ & 360,54 & 0,78 & 7,60 & 129 \\
\hline XVI. Середньобузька височинна область & 1549,15 & 3,37 & 2,66 & 45 \\
\hline ХVII. Центральнопридніпровська височинна область & 1052,59 & 2,29 & 6,03 & 103 \\
\hline ХVIII. Південно-Подільська височинна область & 350,86 & 0,76 & 8,98 & 153 \\
\hline ХІХ. Південно-Придніпровська височинна область & 426,26 & 0,93 & 11,29 & 192 \\
\hline Лівобережно-Дніпровський край & 3161,59 & 6,88 & 6,66 & 113 \\
\hline $\begin{array}{l}\text { XX. Північно-Придніпровська терасова низовинна } \\
\text { область }\end{array}$ & 1201,63 & 2,62 & 5,04 & 86 \\
\hline ХХІ. Північно-Полтавська височинна область & 840,03 & 1,83 & 9,25 & 158 \\
\hline ХХІІ. Східно-Полтавська височинна область & 727,06 & 1,58 & 6,10 & 104 \\
\hline $\begin{array}{l}\text { ХХІІІ. Південно-Придніпровська терасова низовинна } \\
\text { область }\end{array}$ & 392,87 & 0,85 & 7,09 & 121 \\
\hline Східно-Український край & 2927,69 & 6,37 & 2,91 & 50 \\
\hline ХХІV.Сумська схилово-височинна область & 542,65 & 1,18 & 5,33 & 91 \\
\hline ХХV. Харківська схилово-височинна область & 2385,04 & 5,19 & 2,35 & 40 \\
\hline
\end{tabular}


Продовження Таблиці 1

\begin{tabular}{|c|c|c|c|c|}
\hline 1 & 2 & 3 & 4 & 5 \\
\hline Степова зона & 18578,27 & 40,42 & 7,50 & 128 \\
\hline Північностепова підзона & 13531,76 & 29,45 & 7,96 & 136 \\
\hline Дністровсько-Дніпровський край & 4007,57 & 8,72 & 6,34 & 108 \\
\hline ХХVІ. Південно-Молдавська схилово-височинна область & 259,38 & 0,56 & 8,93 & 152 \\
\hline ХХVІІ. Південно-Подільська схилово-височинна область & 379,12 & 0,82 & 7,79 & 133 \\
\hline $\begin{array}{l}\text { ХХVІІІ.Південно-Придніпровська схилово-височинна } \\
\text { область }\end{array}$ & 3369,25 & 7,34 & 5,98 & 102 \\
\hline Лівобережно-Дніпровсько-Приазовський край & 3025,25 & 6,58 & 9,35 & 159 \\
\hline ХХІХ.Орільсько-Самарська низовинна область & 815,99 & 1,78 & 17,13 & 292 \\
\hline ХХХ. Кінсько-Ялинська низовинна область & 1264,13 & 2,74 & 7,31 & 125 \\
\hline ХХХІ. Приазовська височинна область & 351,72 & 0,77 & 8,70 & 148 \\
\hline ХХХІІ. Приазовська низовинна область & 593,41 & 1,29 & 2,58 & 44 \\
\hline Донецький край & 5717,76 & 12,45 & 6,76 & 115 \\
\hline ХХХІІІІ. Західно-Донечьька схилово-височинна область & 1570,04 & 3,42 & 9,40 & 160 \\
\hline XXXIV. Донечька височинна область & 4147,72 & 9,03 & 5,75 & 98 \\
\hline Задонецько-Донський край & 781,18 & 1,70 & 19,65 & 335 \\
\hline ХХХV. Старобільська схилово-височинна область & 781,18 & 1,70 & 19,65 & 335 \\
\hline Середньостепова підзона & 3040,41 & 6,61 & 4,45 & 76 \\
\hline Причорноморський край & 3040,41 & 6,61 & 4,45 & 76 \\
\hline $\begin{array}{l}\text { ХХХVI. Задністровсько-Причорноморська низовинна } \\
\text { область }\end{array}$ & 288,54 & 0,63 & 7,07 & 120 \\
\hline ХХХVІІ. Дністровсько-Бузька низовинна область & 1332,78 & 2,88 & 1,82 & 31 \\
\hline ХХХИІІІ.Бузько-Дніпровська низовинна область & 898,95 & 1,96 & 5,02 & 86 \\
\hline ХХХІХ. Дніпровсько-Молочанська низовинна область & 287,82 & 0,63 & 9,36 & 159 \\
\hline XL. Західно-Приазовська схилово-височинна область & 232,32 & 0,51 & 8,09 & 138 \\
\hline Південностепова (сухостепова) підзона & 2006,10 & 4,36 & 9,02 & 154 \\
\hline Причорноморсько-Приазовський край & 967,35 & 2,10 & 7,81 & 133 \\
\hline XLI. Нижньобузько-Дніпровська низовинна область & 96,96 & 0,21 & 21,10 & 359 \\
\hline $\begin{array}{l}\text { XLII. Нижньоодніпровська терасово-дельтова низовинна } \\
\text { область }\end{array}$ & 528,51 & 1,15 & 3,33 & 57 \\
\hline XLIII. Присивасько-Приазовська низовинна область & 341,88 & 0,74 & 10,97 & 187 \\
\hline Кримський степовий край & 1038,77 & 2,26 & 10,14 & 173 \\
\hline XLIV. Присивасько-Кримська низовинна область & 263,03 & 0,57 & 11,72 & 200 \\
\hline XLV.Тарханкутська височинна область & 199,42 & 0,43 & 12,43 & 212 \\
\hline XLVI. Центральнокримська височинна область & 256,34 & 0,56 & 14,75 & 251 \\
\hline XLVII.Керченська горбистопасмова область & 319,98 & 0,70 & 3,72 & 63 \\
\hline КРИМСЬКІ ГОРИ & 1296,79 & 2,82 & 3,87 & 66 \\
\hline Кримський гірський край & 1296,79 & 2,82 & 3,87 & 66 \\
\hline І.Передгірно-Кримська область & 820,78 & 1,78 & 2,73 & 47 \\
\hline II. Гірсько-Кримська область & 142,27 & 0,31 & 13,69 & 233 \\
\hline III. Південнобережно-Кримська область & 333,74 & 0,73 & 2,48 & 42 \\
\hline
\end{tabular}


Продовження Таблищі 1

\begin{tabular}{|l|c|c|c|c|}
\hline \multicolumn{1}{|c|}{1} & 2 & 3 & 4 & 5 \\
\hline УКРАЇнСьКІ КАРПАТИ & 3747,95 & 8,16 & 4,63 & 79 \\
\hline I.Передкарпатська височинна область & 1819,78 & 3,96 & 3,50 & 60 \\
\hline II. Зовнішньо-Карпатська область & 563,30 & 1,23 & 5,62 & 96 \\
\hline III. Вододільно-Верховинська область & 164,94 & 0,36 & 12,05 & 205 \\
\hline IV. Полонинсько-Чорногірська область & 267,14 & 0,58 & 7,02 & 120 \\
\hline V. Мармароська область & 21,59 & 0,05 & 10,51 & 179 \\
\hline VI. Вулканічно-міжсгірно-улоговинна область & 442,83 & 0,96 & 4,76 & 81 \\
\hline VII. Закарпатська низовинна область & 468,37 & 1,02 & 3,48 & 59 \\
\hline УКРАїнА & 45964,22 & 100,00 & 5,87 & 100 \\
\hline
\end{tabular}

Лісостеповій зоні - більше 1 , 4 , у Зоні широколистяних лісів та Зоні мішаних лісів - по 11\% населення у кожній.

Перша п’ятірка за чисельністю населення серед природних країв така: Подільсько-Придніпровський край Лісостепової зони більше $13 \%$, Донецький край Північностепової підзони - близько 12,5\%, ЗахідноУкраїнський край Зони широколистяних лісів більше 11\%, Поліський край Зони мішаних лісів - також близько 11\%, Дністровсько-Дніпровський край Північностепової підзони - трохи менше 9\%.

Фізико-географічні області України за кількістю жителів мають значну територіальну диференціацію (див. табл. 1): від 9,03\% - максимум - по Донецькій височинній області Донецького краю - до 0,05\% мінімум - по Мармароській області Українських Карпат. Найбільш заселеними є, окрім вказаної області, Південно-Придніпровська схилововисочинна область Дністровсько-Дніпровського краю (7,34\%), Харківська схилово-височинна область Східно-Українського краю (5,19\%), Передкарпатська височинна область Українських Карпат (3,96\%) та Західно-Донецька схилово-височинна область Донецького краю (3,42\%).

Найменше залюдненими поряд з Мармароською областю $є$ Нижньобузько-Дніпровська низовинна область Причорноморсько-Приазовського краю (0,21\%), Гірсько-Кримська область Кримських гір (0,31\%), Вододільно-Верховинська область Українських Карпат $(0,36 \%)$ та Область НовгородСіверського Полісся Поліського краю (0,46\%).

Забезпеченість населення сумарним ПРП території $\epsilon$ однією 3 найважливіших передумов збалансованого соціально-економічного розвитку.

Цей показник, природно, зазнає за природними регіонами істотного впливу щільності населення. Чим більшою є величина сумарного ПРП природного регіону і чим меншою є чисельність його населення, - тим вищою є забезпеченість ПРП мешканців цього району.

Як засвідчує табл. 1, забезпеченість населення сумарним ПРП найвищою серед природних країн є на Східно-Свропейській рівнині (103 бали), далі Українські Карпати - 79 балів та Кримські гори - 66 балів. Степова зона, Лісостепова зона, Зона мішаних лісів та Зона широколистяних лісів - в такому порядку йде спадання забезпеченості населення ПРП серед природних зон.

Зменшення рівнів забезпеченості населення ПРП по природних (фізико-географічних) областях спостерігається від Нижньобузько-Дніпровської низовинної (360 балів), Орільсько-Самарської низовинної, Центральнокримської височинної, Гірсько-Кримської, Тарханкутської височинної (212 балів) областей до найнижчих рівнів у Харківській схилово-височинній, Київській височинній та Дністровсько-Бузькій низовинній (31 бал) областях.

Висновки. 1. Отримані показники чисельності населення у розрізі природних регіонів України дають можливість розраховувати соціальноекономічні пропорції, баланси за генетично сформованими природно-ресурсними комплексами, що поєднують в собі природні та суспільні продуктивні сили. 2. Оцінка рівнів забезпеченості населення природно-ресурсним потенціалом по фізико-географічних регіонах дозволяє виявляти приховані резерви подальшого збалансованого природно-ресурсного розвитку Української держави.

\section{References:}

1. Čisel'nìst' nâ̂vnogo naselennâ Ukrä̈ni na 1 sičnâ 2012 roku [The number of available population of Ukraine as of 1 January 2012]. State Statistics Service of Ukraine. Kyiv, 2012, 112 p. (In Ukrainian).

2. Marinič O.M., Parhomenko G.O., Petrenko O.M., Šiŝenko P.G. Udoskonalena shema fìziko-geografičnogo rajonuvannâ Ukraïni [An improved scheme of physiographic zoning of Ukraine]. Ukrä̈ns'kij geografičnij žurnal [Ukrainian Geographical Journal], 2003, Vol. 1, pp. 16-20. (In Ukrainian).

3. Fiziko-geografičeskoe rajonirovanie Ukrainskoj SSR [Physiographic zoning of Ukrainian SSR]. Kyiv, 1968, 683 p. (In Russian).

4. Rudenko V.P., Rudenko S.V. Ocinka prirodno-resursnogo potencialu Ukraïni âk osnova menedžmentu prirodoohoronnoï diâl'nostì [Assessment of natural resource potential of Ukraine as a basis for management of environmental activities]. Chernivtsi, 2014, 248 p. (In Ukrainian). 